\title{
PENGARUH GEOMETRI JARINGAN TERHADAP KETELITIAN SURVEY GPS
}

\author{
Hasanuddin Z. Abidin dan Fajar T. Mugiarto \\ Jurusan Teknik Geodesi, Institut Teknologi Bandung \\ Jl. Ganesha 10, Bandung 40132 \\ E-mail : hzabidin@gd.itb.ac.id
}

\begin{abstract}
ABSTRAK
Kualitas dari koordinat titik-titik dalam suatu jaringan yang diperoleh dengan survey GPS secara umum akan tergantung pada empat faktor yaitu : ketelitian data yang digunakan, geometri pengamatan, strategi pengamatan yang digunakan, dan strategi pengolahan data yang diterapkan. Geometri pengamatan sendiri merupakan kombinasi dari geometri jaringan dan geometri satelit.

Dalam makalah ini akan dibahas pengaruh dari faktor geometri jaringan terhadap kualitas koordinat yang diperoleh dari hitung perataan jaringan GPS. Dalam hal ini parameter dari geometri jaringan yang akan ditinjau pengaruhnya terhadap ketelitian survey GPS adalah : jumlah dan distribusi dari titik tetap (titik kontrol), jumlah baseline dalam satu loop, serta konektivitas titik (jumlah baseline yang terikat ke suatu titik). Pembahasan akan didasarkan pada hasil-hasil yang diperoleh dari pengolahan data jaringan GPS Orde-3 Badan Pertanahan Nasional (BPN) di daerah Purwodadi dan Wates. Makalah akan diakhiri dengan beberapa catatan penutup.
\end{abstract}

\section{PENDAHULUAN}

GPS adalah sistem radio navigasi dan penentuan posisi menggunakan satelit yang dimiliki dan dikelola oleh Amerika Serikat. Sistem yang dapat digunakan oleh banyak orang sekaligus dalam segala cuaca ini, didesain untuk memberikan posisi dan kecepatan tiga-dimensi yang teliti dan juga informasi mengenai waktu secara kontinyu di seluruh dunia. Saat ini GPS telah sangat banyak digunakan orang di seluruh dunia dalam berbagai bidang untuk bermacam ragam keperluan [Abidin, 1995]. Salah satu dari aplikasi GPS ini adalah dalam bidang survey dan pemetaan, terutama untuk keperluan penentuan koordinat dari titik-titik di permukaan bumi.

Survey penentuan posisi dengan GPS (survey GPS) secara umum dapat didefinisikan sebagai proses penentuan koordinat dari sejumlah titik terhadap beberapa buah titik yang telah diketahui koordinatnya, dengan menggunakan metode penentuan posisi diferensial (differential positioning) serta data pengamatan fase (carrier phase) dari sinyal GPS. Pada suatu survey dengan GPS [Abidin et al., 1995], pengamatan GPS dengan selang waktu tertentu dilakukan baseline per baseline dalam suatu jaringan dari titiktitik yang akan ditentukan posisinya. Seandainya lebih dari dua receiver GPS yang digunakan, maka pada satu sesi pengamatan (observing session) dapat diamati lebih dari satu baseline sekaligus.

Pada survey GPS, proses pengolahan data untuk penentuan koordinat dari titik-titik dalam suatu jaringan pada dasarnya terdiri atas tiga tahap, yaitu :

- Pengolahan data dari setiap baseline dalam jaringan,

- Perataan jaringan yang melibatkan semua baseline untuk menentukan koordinat final dari titik-titik dalam jaringan, dan

- Transformasi koordinat titik-titik tersebut dari datum WGS84 ke datum yang diperlukan oleh pengguna. 
Ketelitian dari koordinat titik-titik yang diperoleh dari suatu survey GPS (dalam tulisan ini dimaksudkan sebagai ketelitian survey GPS) secara umum akan tergantung pada empat faktor yaitu : ketelitian data yang digunakan, geometri pengamatan, strategi pengamatan yang digunakan, dan strategi pengolahan data yang diterapkan, seperti yang ditunjukkan pada Gambar 1 berikut. Tergantung pada bagaimana kita memperhitungkan dan memperlakukan faktor-faktor tersebut, maka kita akan memperoleh tingkat ketelitian yang berbeda-beda.

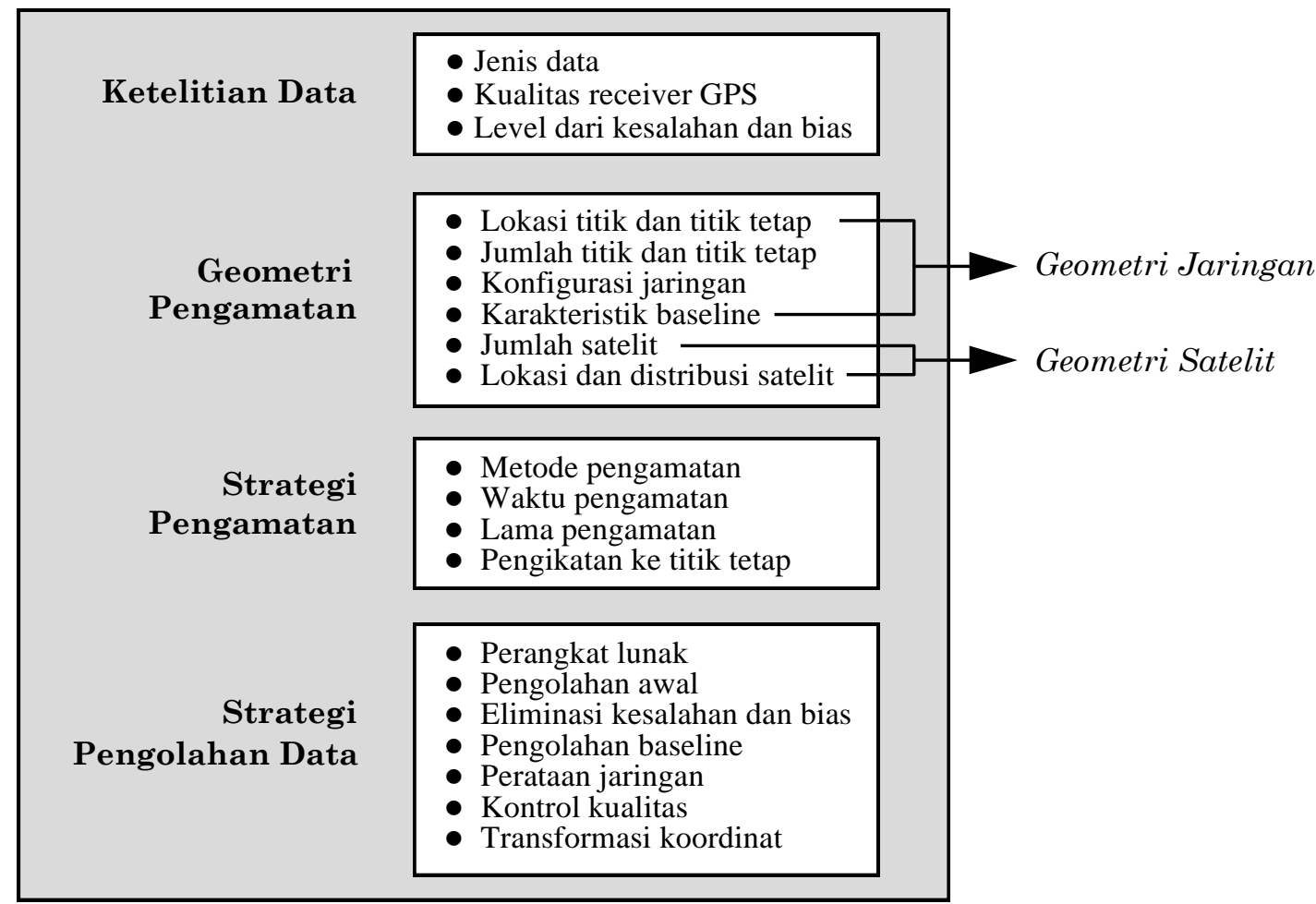

Gambar 1. Faktor-faktor yang mempengaruhi ketelitian survey GPS.

Dalam makalah ini, akan dibahas pengaruh dari satu faktor saja, yaitu pengaruh geometri jaringan, terhadap ketelitian koordinat yang diperoleh dari hitung perataan jaring GPS. Faktor geometri jaringan sendiri akan ditentukan oleh beberapa parameter, seperti yang diindikasikan pada Gambar 1. Dalam hal ini parameter dari geometri jaringan yang akan ditinjau pengaruhnya terhadap ketelitian survey GPS adalah :

- jumlah dan lokasi dari titik tetap (titik kontrol),

- jumlah baseline dalam satu loop, serta

- konektivitas titik (jumlah baseline yang terikat ke suatu titik).

Pembahasan akan didasarkan pada hasil-hasil yang diperoleh dari pengolahan data jaringan GPS Orde-3 Badan Pertanahan Nasional (BPN) di daerah Purwodadi dan Wates. Pengolahan data dilakukan dengan menggunakan perangkat lunak perataan jaringan GEOLAB.

\section{HITUNG PERATAAN JARING GPS}

Pengolahan data suatu jaringan survey GPS akan melibatkan sejumlah vektor baseline serta beberapa titik kontrol yang sudah diketahui koordinatnya dalam sistem WGS 1984. Hitung perataan tersebut umumnya dilakukan menggunakan hitung perataan kuadrat terkecil, baik dengan metode parameter maupun bersyarat. Persamaan pengamatan dapat disusun dalam sistem koordinat kartesian maupun geodetik. Berikut ini penjelasan tentang konsep hitung perataan jaring GPS, mengasumsikan penggunaan metode parameter dalam sistem koordinat kartesian. Untuk memudahkan penjelasan, 
model matematis untuk satu baseline yang geometrinya ditunjukkan pada Gambar 2, akan dijelaskan terlebih dahulu sebelum model matematis yang mencakup suatu jaringan diberikan. Penjelasan yang lebih mendetil tentang hitung perataan jaring GPS dapat dilihat di [Leick, 1995].

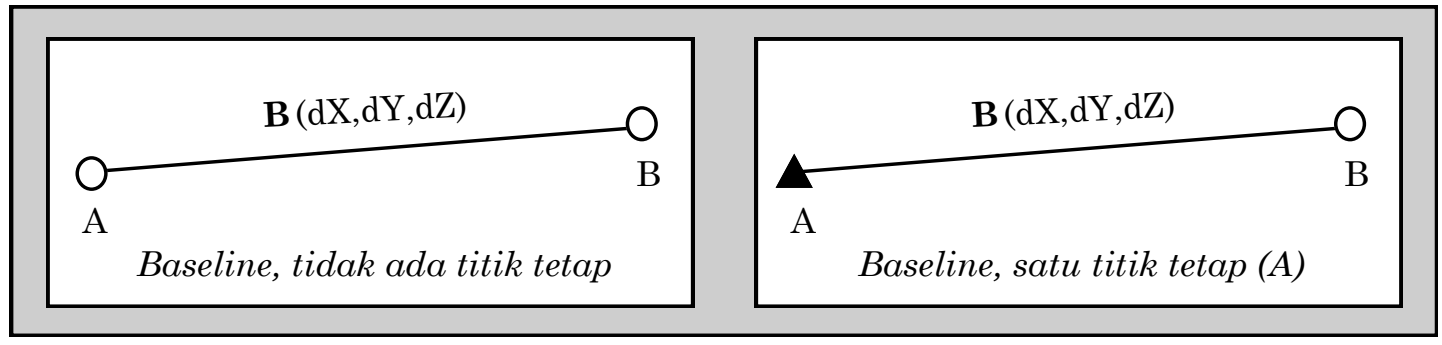

Gambar 2. Dua kasus geometri suatu vektor baseline (lepas dan terikat).

Pada hitung perataan kuadrat terkecil metode parameter, persamaan pengamatan suatu vektor baseline yang lepas, seperti yang ditunjukkan pada Gambar 1 (bagian kiri), dapat dituliskan dalam bentuk persamaan vektor sebagai berikut :

$$
\mathbf{V}+\mathbf{B}=\mathbf{X}_{\mathbf{B}}-\mathbf{X}_{\mathbf{A}}
$$

dimana $\mathbf{B}\left(\mathrm{dX}_{\mathrm{AB}}, \mathrm{dY}_{\mathrm{AB}}, \mathrm{d} \mathrm{Z}_{\mathrm{AB}}\right)$ adalah 'data ukuran' vektor baseline yang merupakan hasil dari perhitungan baseline, $\mathbf{V}\left(\mathrm{v}_{\mathrm{x}}, \mathrm{v}_{\mathrm{y}}, \mathrm{v}_{\mathrm{z}}\right)$ adalah vektor residual yang juga dapat dilihat sebagai vektor koreksi terhadap vektor baseline, dan $\mathbf{x}_{A}\left(X_{A}, Y_{A}, Z_{A}\right)$ serta $\mathbf{x}_{B}\left(X_{B}, Y_{B}, Z_{B}\right)$ adalah vektor posisi geosentrik dari titik-titik A dan B yang akan ditentukan harganya (merupakan parameter yang dicari). Dalam formulasi matriks, persamaan (1) di atas dapat ditulis juga sebagai berikut :

$$
\mathbf{V}=\left[\begin{array}{ll}
-\mathbf{I} & \mathbf{I}
\end{array}\right] \cdot\left[\begin{array}{l}
\mathbf{X}_{\mathrm{A}} \\
\mathbf{X}_{\mathbf{B}}
\end{array}\right]+\mathbf{B}
$$

dimana I adalah matriks identitas berdimensi $(3 \times 3)$. Persamaan di atas dapat diuraikan kembali dalam bentuk formulasi berikut :

$$
\left[\begin{array}{l}
\mathrm{v}_{\mathrm{X}} \\
\mathrm{v}_{\mathrm{y}} \\
\mathrm{v}_{\mathrm{z}}
\end{array}\right]=\left[\begin{array}{cccccc}
-1 & 0 & 0 & 1 & 0 & 0 \\
0 & -1 & 0 & 0 & 1 & 0 \\
0 & 0 & -1 & 0 & 0 & 1
\end{array}\right] \cdot\left[\begin{array}{l}
\mathrm{x}_{\mathrm{A}} \\
\mathrm{y}_{\mathrm{A}} \\
\mathrm{z}_{\mathrm{A}} \\
\mathrm{x}_{\mathrm{B}} \\
\mathrm{x}_{\mathrm{B}} \\
\mathrm{z}_{\mathrm{A}}
\end{array}\right]-\left[\begin{array}{c}
\mathrm{d} \mathrm{X}_{\mathrm{AB}} \\
\mathrm{d} \mathrm{Y}_{\mathrm{AB}} \\
\mathrm{dz_{AB }}
\end{array}\right] .
$$

Kalau seandainya kita mengacu pada formulasi yang umum digunakan persamaan pengamatan dari hitung perataan parameter :

$$
\mathbf{v}=\mathbf{A} \mathbf{X}-\mathbf{L},
$$

dimana $\mathbf{V}$ adalah vektor residu, $\mathbf{A}$ adalah matriks desain, $\mathbf{X}$ adalah vektor parameter, dan $\mathbf{L}$ adalah vektor pengamatan; maka matriks desain $\mathbf{A}$ untuk suatu baseline lepas adalah :

$$
\mathbf{A}=\left[\begin{array}{ll}
-\mathbf{I} & \mathbf{I}
\end{array}\right]=\left[\begin{array}{rrrrrr}
-1 & 0 & 0 & 1 & 0 & 0 \\
0 & -1 & 0 & 0 & 1 & 0 \\
0 & 0 & -1 & 0 & 0 & 1
\end{array}\right],
$$

dan vektor-vektor parameter dan pengamatannya adalah : 


$$
\begin{aligned}
& \mathbf{x}=\left[\mathrm{X}_{\mathrm{A}}, \mathrm{Y}_{\mathrm{A}}, Z_{\mathrm{A}}, \mathrm{X}_{\mathrm{B}}, \mathrm{Y}_{\mathrm{B}}, Z_{\mathrm{B}}\right]^{\mathrm{T}}, \\
& \mathbf{L}=\left[\mathrm{dX}_{\mathrm{AB}}, \mathrm{dY}_{\mathrm{AB}}, \mathrm{d} \mathrm{Z}_{\mathrm{AB}}\right]^{\mathrm{T}} .
\end{aligned}
$$

Untuk suatu vektor baseline yang terikat, dimana salah satu titik ujungnya merupakan titik kontrol, seperti yang dicontohkan pada Gambar 2 (bagian kanan), maka karena $\mathbf{X}_{\mathrm{A}}$ sudah diketahui harganya, persamaan pengamatannya menjadi seperti berikut :

$$
\left[\begin{array}{c}
v_{X} \\
v_{Y} \\
v_{z}
\end{array}\right]=\left[\begin{array}{lll}
1 & 0 & 0 \\
0 & 1 & 0 \\
0 & 0 & 1
\end{array}\right] \cdot\left[\begin{array}{c}
X_{B} \\
Y_{B} \\
Z_{B}
\end{array}\right]-\left[\begin{array}{cc}
x_{A}+d X_{A B} \\
Y_{A}+d Y_{A B} \\
z_{A}+d z_{A B}
\end{array}\right],
$$

dimana kalau kita mengacu pada persamaan (4) :

$$
\begin{aligned}
& \mathbf{A}=\mathbf{I} \\
& \mathbf{x}=\left[\mathrm{X}_{\mathrm{B}}, \mathrm{Y}_{\mathrm{B}}, \mathrm{Z}_{\mathrm{B}}\right]^{\mathrm{T}}, \\
& \mathbf{L}=\left[\mathrm{X}_{\mathrm{A}}+\mathrm{d} \mathrm{X}_{\mathrm{AB}}, \mathrm{Y}_{\mathrm{A}}+\mathrm{d} \mathrm{Y}_{\mathrm{AB}}, Z_{\mathrm{A}}+\mathrm{d} Z_{\mathrm{AB}}\right]^{\mathrm{T}} .
\end{aligned}
$$

Untuk menjelaskan persamaan pengamatan dari suatu hitung perataan jaring GPS, konfigurasi yang ditunjukkan pada Gambar 3 akan digunakan. Pada jaringan ini ada 3 titik kontrol yang digunakan, 10 data ukuran vektor baseline, serta 5 titik yang akan ditentukan koordinatnya. Ini berati ada 30 data ukuran serta 15 parameter yang akan ditentukan harganya.

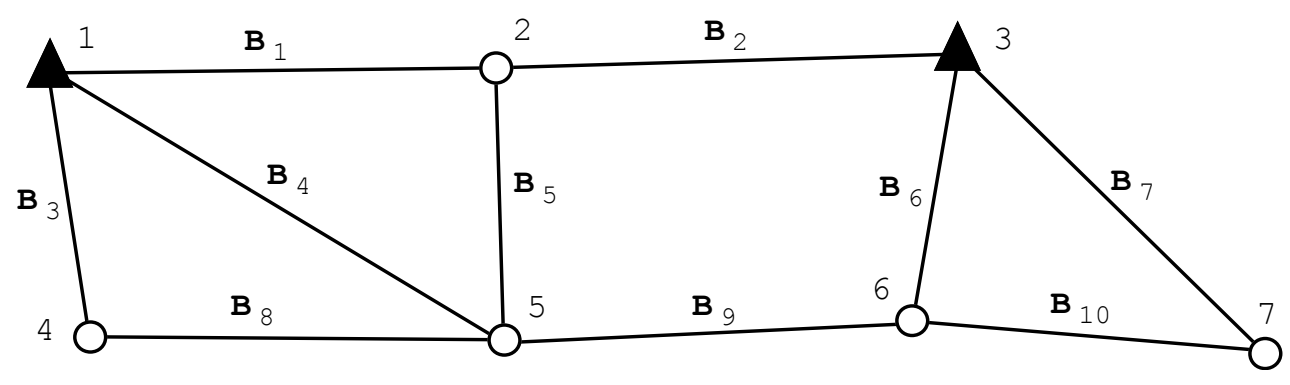

Gambar 3. Contoh suatu jaringan GPS

Untuk contoh jaringan GPS seperti yang ditunjukkan pada Gambar 4, maka persamaan pengamatannya dapat dituliskan sebagai berikut :

$$
\begin{aligned}
& \mathbf{V}_{1}+\mathbf{B}_{1}=\mathbf{X}_{2}-\mathbf{X}_{1}, \\
& \mathbf{V}_{2}+\mathbf{B}_{2}=\mathbf{X}_{3}-\mathbf{X}_{2}, \\
& \mathbf{V}_{3}+\mathbf{B}_{3}=\mathbf{X}_{4}-\mathbf{X}_{1}, \\
& \mathbf{V}_{4}+\mathbf{B}_{4}=\mathbf{X}_{5}-\mathbf{X}_{1}, \\
& \mathbf{V}_{5}+\mathbf{B}_{5}=\mathbf{X}_{5}-\mathbf{X}_{2}, \\
& \mathbf{V}_{6}+\mathbf{B}_{6}=\mathbf{X}_{6}-\mathbf{X}_{3}, \\
& \mathbf{V}_{7}+\mathbf{B}_{7}=\mathbf{X}_{7}-\mathbf{X}_{3}, \\
& \mathbf{V}_{8}+\mathbf{B}_{8}=\mathbf{X}_{5}-\mathbf{X}_{4}, \\
& \mathbf{V}_{9}+\mathbf{B}_{9}=\mathbf{X}_{6}-\mathbf{X}_{5}, \\
& \mathbf{V}_{10}+\mathbf{B}_{10}=\mathbf{X}_{7}-\mathbf{X}_{6} .
\end{aligned}
$$

Dari persamaan pengamatan di atas, maka matriks desain $\mathbf{A}$ serta vektor parameter $\mathbf{X}$ dan vektor pengamatan $\mathbf{L}$ dapat diformulasikan sebagai berikut : 


$$
\mathbf{A}=\left[\begin{array}{rrrrr}
\mathbf{I} & 0 & 0 & 0 & 0 \\
-I & 0 & 0 & 0 & 0 \\
0 & I & 0 & 0 & 0 \\
0 & 0 & I & 0 & 0 \\
-I & 0 & I & 0 & 0 \\
0 & 0 & 0 & I & 0 \\
0 & 0 & 0 & 0 & I \\
0 & -I & I & 0 & 0 \\
0 & 0 & -I & I & 0 \\
0 & 0 & 0 & -I & I
\end{array}\right], \quad X=\left[\begin{array}{c}
\mathbf{X}_{2} \\
\mathbf{X}_{4} \\
\mathbf{X}_{5} \\
\mathbf{X}_{6} \\
\mathbf{X}_{7}
\end{array}\right], \quad \mathbf{I}=\left[\begin{array}{c}
\mathbf{B}_{1}+\mathbf{X}_{1} \\
\mathbf{B}_{2}-\mathbf{X}_{3} \\
\mathbf{B}_{3}+\mathbf{X}_{1} \\
\mathbf{B}_{4}+\mathbf{X}_{1} \\
\mathbf{B}_{5} \\
\mathbf{B}_{6}+\mathbf{X}_{3} \\
\mathbf{B}_{7}+\mathbf{X}_{3} \\
\mathbf{B}_{8} \\
\mathbf{B}_{9} \\
\mathbf{B}_{10}
\end{array}\right]
$$

dimana I dan $\mathbf{O}$ adalah masing-masing matriks satuan dan matriks nol berdimensi $(3,3)$. Selanjutnya solusi kuadrat terkecil untuk koordinat titik-titik dalam jaringan adalah :

$$
\mathbf{X}=\left(\mathbf{A}^{\mathbf{T}} \cdot \mathbf{P}_{\mathbf{L}} \cdot \mathbf{A}\right)^{-1} \cdot \mathbf{A}^{\mathbf{T}} \cdot \mathbf{P}_{\mathbf{L}} \cdot \mathbf{L}
$$

dimana $\mathbf{P}_{\mathbf{L}}$ adalah matriks berat dari pengamatan yang dapat dirumuskan sebagai berikut :

$$
\mathbf{P}_{\mathbf{L}}=\mathbf{Q}_{\mathbf{L}}^{-1}=\sigma_{\mathrm{O}}^{2} \cdot \mathbf{C}_{\mathbf{L}}^{-1}
$$

Pada rumus di atas, $\mathbf{Q}_{\mathbf{L}}$ adalah matriks kofaktor, $\sigma_{\mathrm{o}}^{2}$ adalah faktor variansi apriori (biasanya ditetapkan $=1$ ), dan $\mathbf{C}_{\mathbf{L}}$ adalah matriks variansi kovariansi $(\mathrm{VCV}$ ) pengamatan yang dapat diformulasikan sebagai :

$$
C_{L}=\left[\begin{array}{ccccc}
C\left(B_{1}\right) & 0 & 0 & \cdots & 0 \\
0 & C\left(B_{2}\right) & 0 & \cdots & 0 \\
0 & 0 & C\left(B_{3}\right) & \cdots & 0 \\
\cdots & \cdots & \cdots & \cdots & 0 \\
0 & 0 & 0 & 0 & C\left(B_{10}\right)
\end{array}\right] .
$$

Pada rumus (16) di atas, matriks VCV dari setiap vektor baseline, $\mathbf{C}\left(\mathbf{B}_{\mathbf{i}}\right)$, diperoleh dari hasil hitung perataan baseline, dan akan mempunyai struktur sebagai berikut :

$$
\mathbf{C}\left(\mathbf{B}_{i}\right)=\left[\begin{array}{ccc}
\sigma_{d X_{i}}^{2} & \sigma_{d X_{i} d Y_{i}} & \sigma_{d X_{i} d z_{i}} \\
& \sigma_{d Y_{i}}^{2} & \sigma_{d Y_{i} d z_{i}} \\
\text { simetrik } & & \sigma_{d Z_{i}}^{2}
\end{array}\right] .
$$

Matriks VCV dari koordinat titik-titik dalam jaringan yang diperoleh dari hasil hitung perataan dapat ditentukan dengan rumus berikut:

$$
C_{\mathbf{X}}=\hat{\sigma}_{\mathrm{O}}^{2} \cdot\left(\mathbf{A}^{\mathrm{T}} \cdot \mathrm{P}_{\mathrm{L}} \cdot \mathbf{A}\right)^{-1},
$$

dimana $\hat{\sigma}_{\mathrm{o}}^{2}$ adalah faktor variansi aposteori yang dihitung sebagai berikut :

$$
\hat{\sigma}_{0}^{2}=\frac{\mathrm{V}^{\mathrm{T}} \cdot \mathrm{P}_{\mathrm{L}} \cdot \mathrm{V}}{\mathrm{n}-\mathrm{u}}
$$


Pada rumus (19) di atas, $\mathrm{n}$ dan $\mathrm{u}$ masing-masing adalah jumlah data pengamatan dan jumlah paramaeter yang diestimasi. Pada contoh jaringan GPS yang ditunjukkan pada Gambar 4, maka $\mathrm{n}=30$ (10 baseline $\mathrm{x} 3$ komponen per baseline) dan $\mathrm{u}=15$ (5 titik x 3 komponen koordinat per titik). Dalam hal ini dikatakan jaringan GPS tersebut mempunyai ukuran lebih (redundancy) sebanyak $(30-15)=15$.

\section{GEOMETRI JARING GPS}

Geometri dari suatu jaringan survey GPS dapat dikarakterisir dengan beberapa parameter, seperti jumlah dan lokasi titik dalam jaringan (termasuk titik tetap), jumlah baseline dalam jaringan (termasuk common baseline), konfigurasi baseline dan loop, serta konektivitas titik dalam jaringan. Beberapa dari paramater tersebut divisualisasikan pada Gambar 4 berikut.

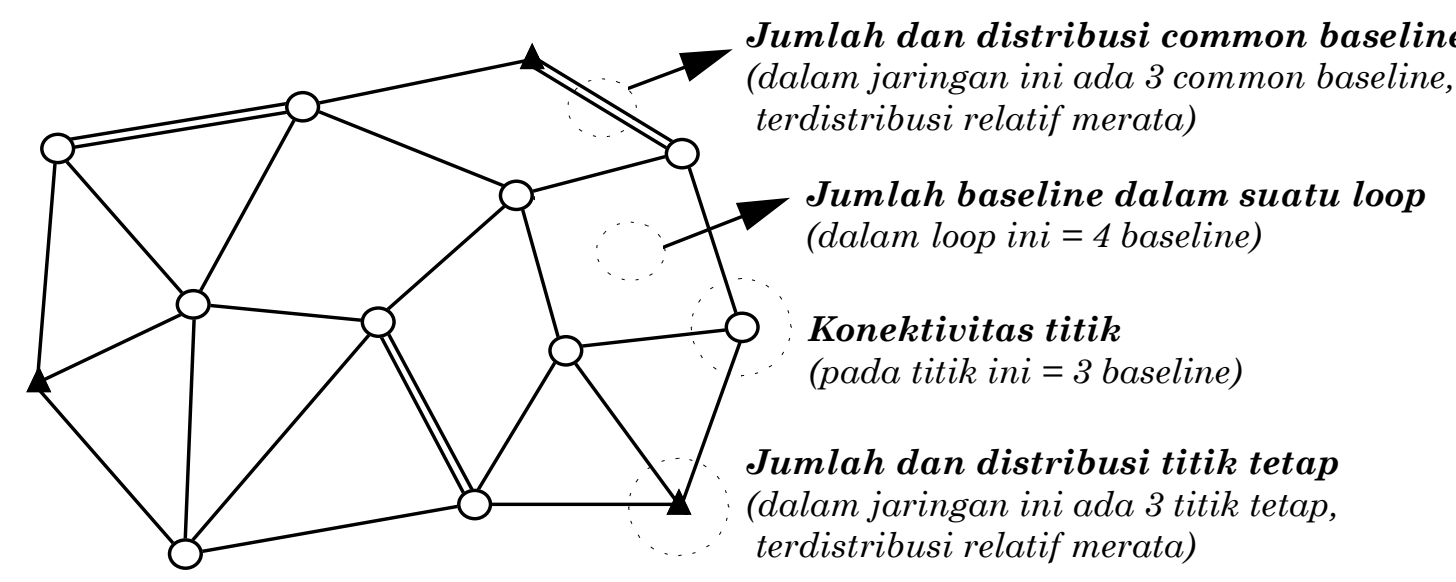

Gambar 4. Beberapa parameter dari geometri jaringan GPS.

Kekuatan geometri jaringan GPS akan sangat tergantung pada karakteristik yang diadopsi dari parameter-parameter tersebut. Untuk jumlah titik dalam jaringan yang sama, beberapa bentuk konfigurasi jaringan dapat dibuat tergantung pada karakteristik parameter geometri jaringan yang digunakan. Ada beberapa parameter dan kriteria yang dapat digunakan untuk menentukan konfigurasi jaringan yang paling baik. Salah satunya adalah didasarkan pada persamaan (18) di atas yang menggambarkan tingkat ketelitian dari koordinat titik-titik dalam jaringan. Dengan mengasumsikan faktor variansi aposteriori sama dengan satu serta ketelitian vektor baseline dan vektor koordinat yang homogen dan independen antar komponennya, suatu bilangan untuk memprediksi kekuatan jaringan dapat diformulasikan sebagai berikut :

faktor kekuatan jaringan $=\left[\operatorname{trace}\left(\mathbf{A}^{\mathrm{T}} \mathbf{A}\right)^{-1}\right] /$ jumlah parameter.

Dalam hal ini semakin kecil bilangan faktor kekuatan jaringan tersebut di atas, maka akan semakin baik konfigurasi jaringan yang bersangkutan, dan sebaliknya. Pada Tabel 1 diberikan beberapa contoh konfigurasi jaringan berikut nilai faktor kekuatan jaringannya. Tapi perlu ditekankan di sini bahwa kualitas akhir dari survey GPS pada jaringan-jaringan tersebut akan tergantung tidak hanya pada faktor kekuatan jaringan, tapi juga pada faktor-faktor lainnya, yaitu : ketelitian data survey GPS strategi pengamatan yang digunakan, dan strategi pengolahan data yang diterapkan. 
Tabel 1. Contoh Beberapa Konfigurasi Jaringan Dasar 3D dan Tingkat Kekuatannya.

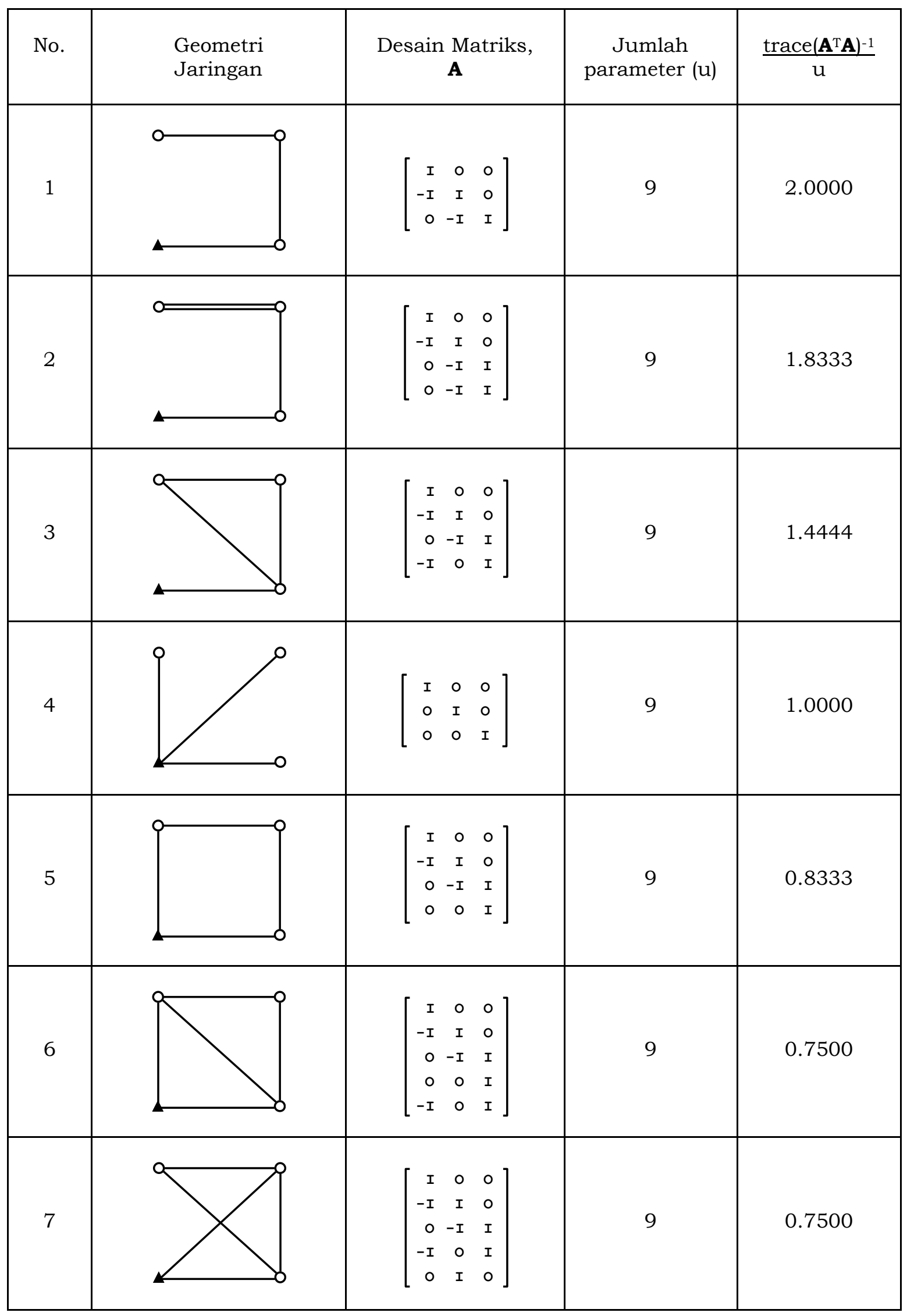


Tabel 1 (Lanjutan)

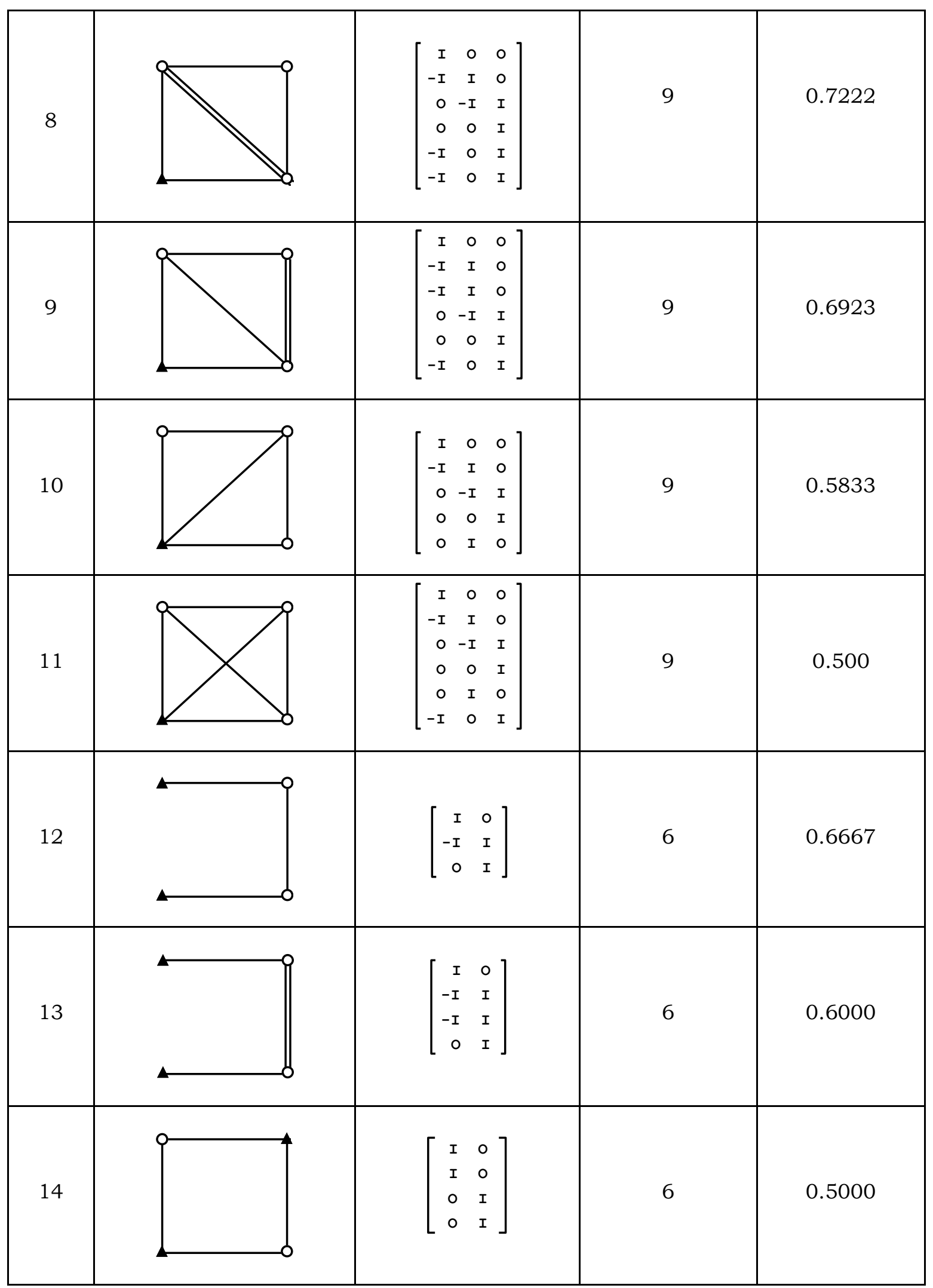


Tabel 1 (Lanjutan)

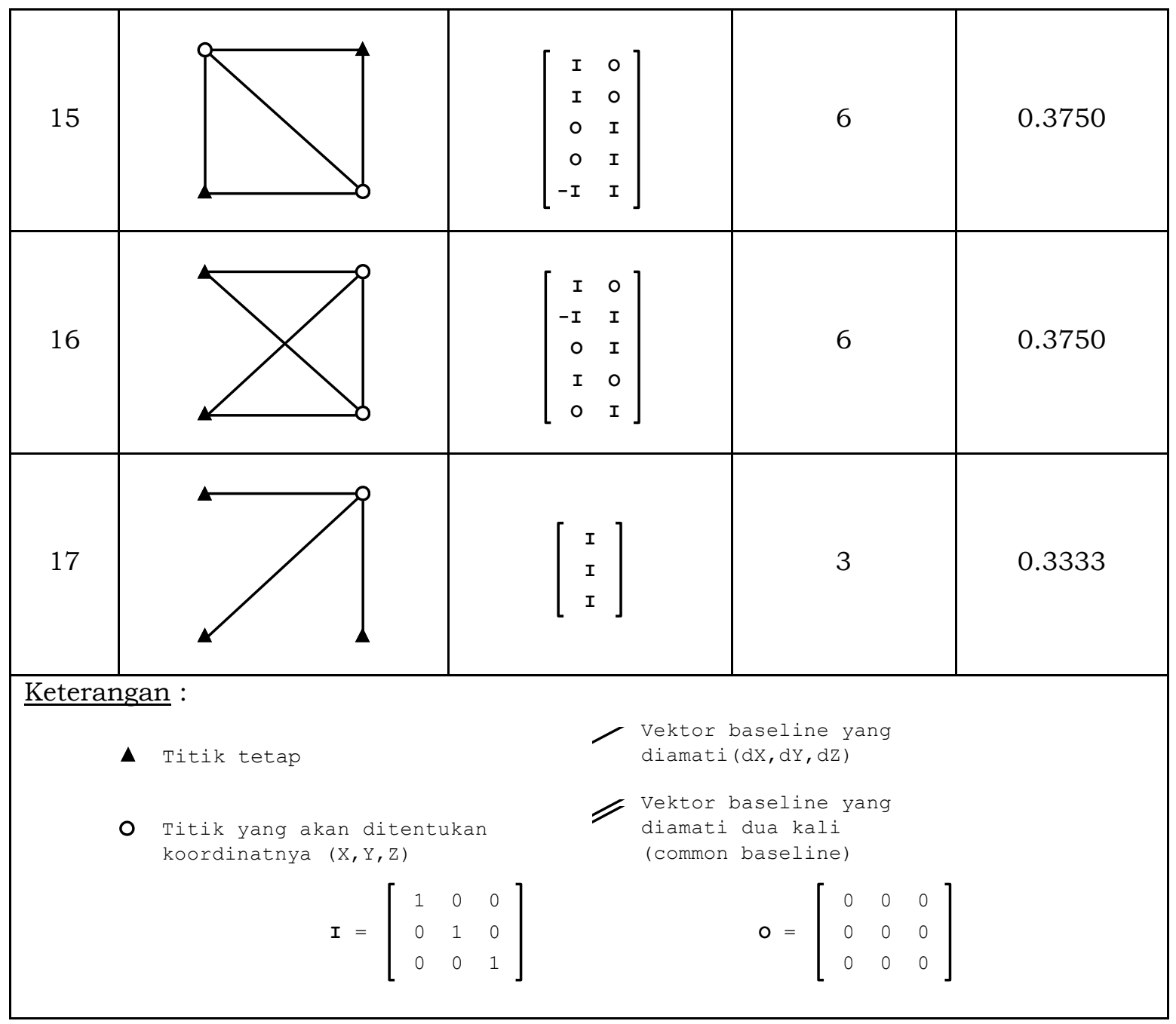

Dari beberapa contoh konfigurasi jaringan yang diberikan pada Tabel 1 di atas terlihat bahwa secara geometris ada beberapa hal yang bisa digunakan untuk memperkuat konfigurasi jaringan, yaitu :

- penambahan jumlah titik tetap,

- penambahan jumlah ukuran baseline,

- peningkatan konektivitas titik,

- pengadaan common baseline,

- penutupan rangkaian baseline dalam suatu loop,

- penambahan jumlah loop dalam jaringan (pengurangan jumlah baseline dalam suatu loop).

\section{DATA JARING GPS UNTUK CONTOH PERHITUNGAN}

Untuk mempelajari efek dari geometri jaringan terhadap ketelitian survey GPS, dalam makalah ini digunakan data jaringan GPS Nasional Orde-3 di Purwodadi dan Wates yang diukur pada tahun 1997. Konfigurasi kedua jaringan tersebut beserta panjang baselinenya ditunjukkan pada Gambar-Gambar 5, 6, dan 7 berikut. Jaring Wates pada Gambar 5 yang digunakan merupakan bagian dari suatu jaringan GPS Orde-3 yang lebih besar. Sedangkan jaringan GPS Orde-3 Purwodadi yang ditunjukkan pada Gambar 6, terdiri dari 72 titik yang terikat pada 4 titik GPS BPN Orde-2. Jaring ini setiap baselinenya diamati dengan menggunakan receiver Trimble 4000 SE selama lebih 
kurang 45 sampai 60 menit, dan pengolahan baselinenya dilakukan dengan software GPSurvey. Sedangkan perataan jaringan dilakukan dengan menggunakan software GEOLAB.
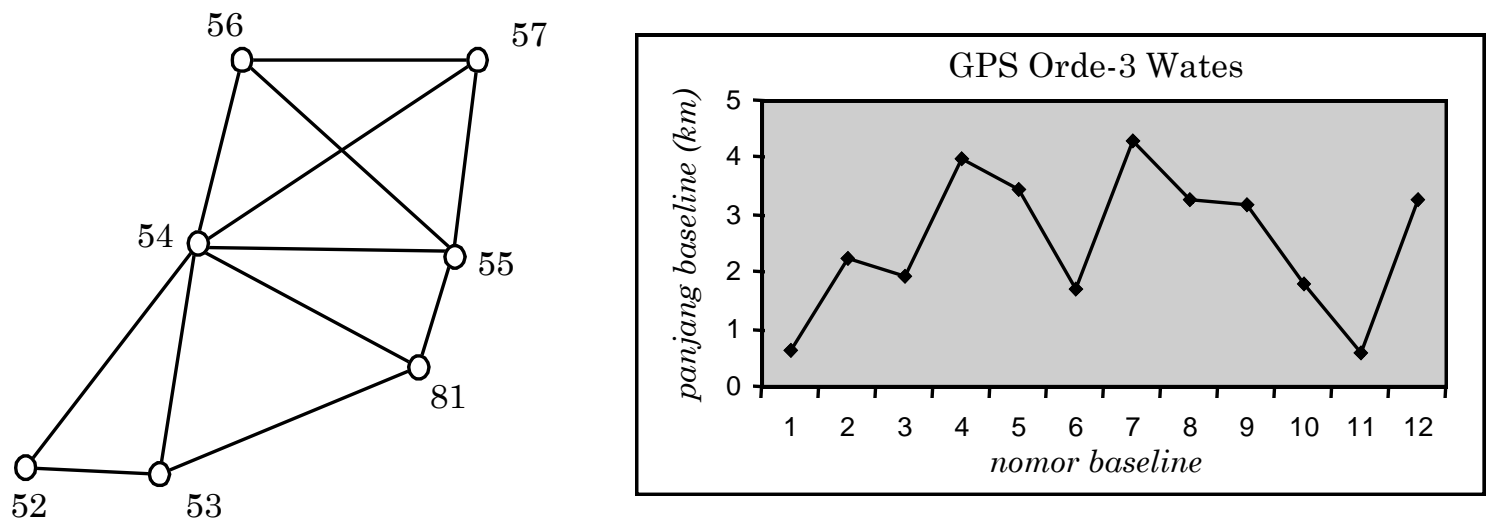

Gambar 5. Konfigurasi dari Sebagian Jaring GPS BPN Orde-3 di Wates dan Panjang Baseline dalam Jaringan.

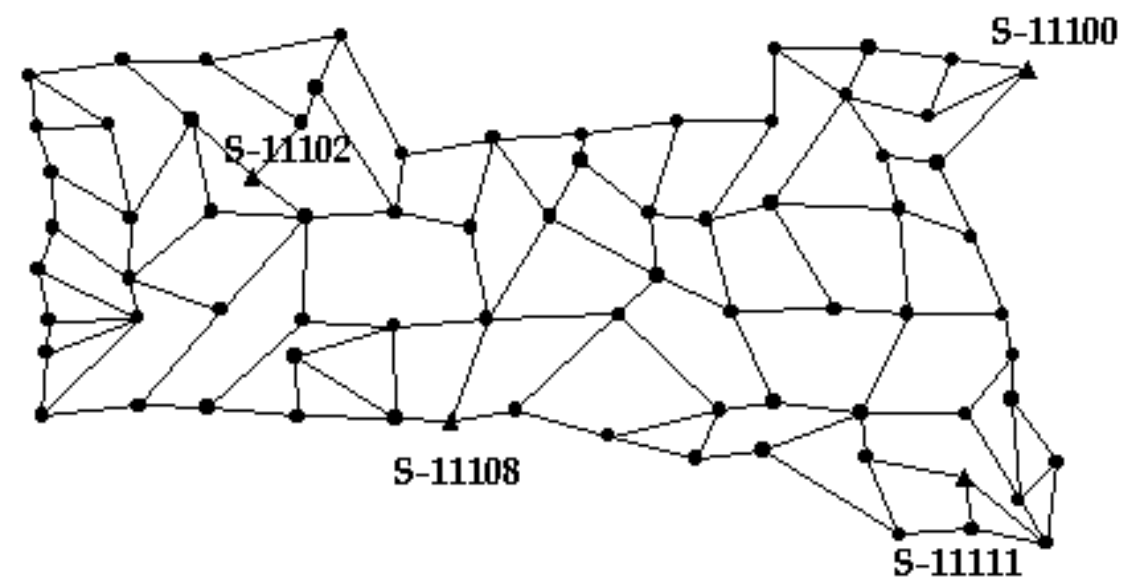

Gambar 6. Konfigurasi Jaring GPS BPN Orde-3 di daerah Purwodadi.

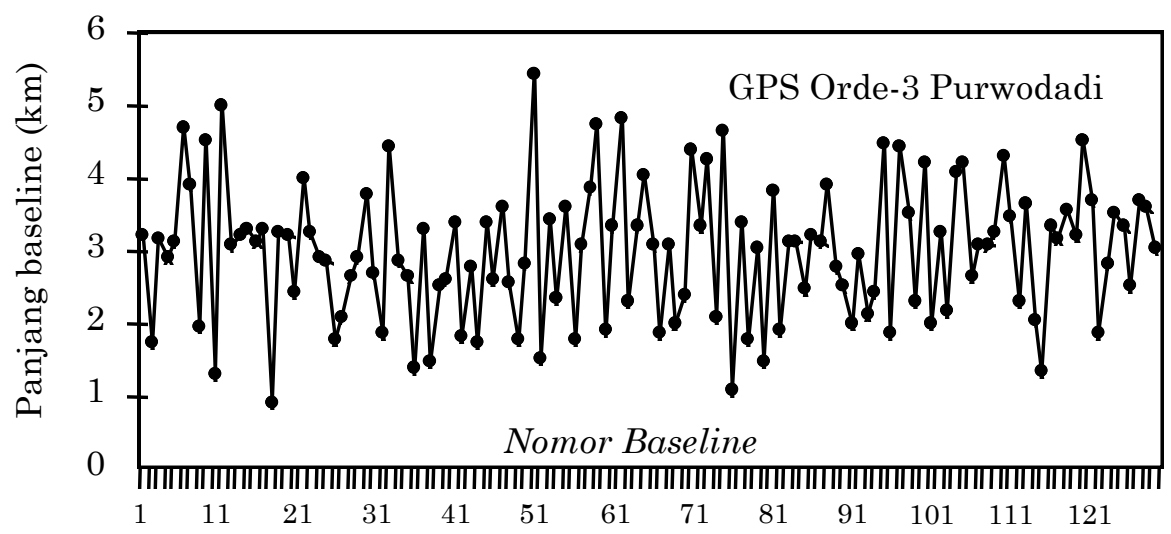

Gambar 7. Panjang Baseline dalam Jaring GPS BPN Orde-3 di daerah Purwodadi.

Perlu ditekankan bahwa dalam hal ini sengaja digunakan data jaringan GPS yang panjang baseline-baselinenya relatif pendek, yaitu lebih pendek dari $5 \mathrm{~km}$. Pada jaringan GPS yang panjang baseline-baselinenya relatif pendek maka dapat diharapkan bahwa efek dari kesalahan-kesalahan orbit, ionosfir, dan troposfir terhadap ketelitian 
survey GPS relatif kecil dan dapat diabaikan. Dengan itu dapat diharapkan bahwa efek dari geometri jaringan akan menjadi relatif dominan dan karakteristiknya akan dapat dipelajari dengan baik.

\section{PENGARUH GEOMETRI JARINGAN}

Berikut ini akan dipelajari pengaruh dari geometri jaringan terhadap kualitas survey GPS. Parameter-parameter geometri jaringan yang akan dipelajari yaitu : jumlah titik tetap, distribusi titik tetap, jumlah baseline dalam suatu loop, serta konektivitas titik.

\subsection{Pengaruh Jumlah Titik Tetap}

Untuk melihat pengaruh dari jumlah titik tetap dalam jaringan, digunakan data jaringan GPS Purwodadi yang ditunjukkan pada Gambar 6. Ada 4 kasus jumlah titik ikat yang dipelajari, yaitu : 1 titik ikat (S-11111), 2 titik ikat (S-11111 dan S-11100), 3 titik ikat (S11111, S-11100, dan S-11102), dan 4 titik ikat (S-11111, S-11100, S-11102, dan S11108).

Secara teoritis, seperti yang diilustrasikan pada Tabel 1, penambahan titik tetap dalam jaringan akan meningkatkan kepresisian dari koordinat titik-titik dalam jaringan. Hal ini terbukti dari hasil yang ditunjukkan pada Gambar 8. Hasil ini juga menunjukkan bahwa penambahan titik tetap dari tiga menjadi empat tidak terlalu memberikan pengaruh yang signifikan. Dari Gambar ini juga terlihat bahwa pengaruh penambahan titik tetap lebih terasa pada komponen tinggi dibandingkan pada komponen horisontal dari koordinat.

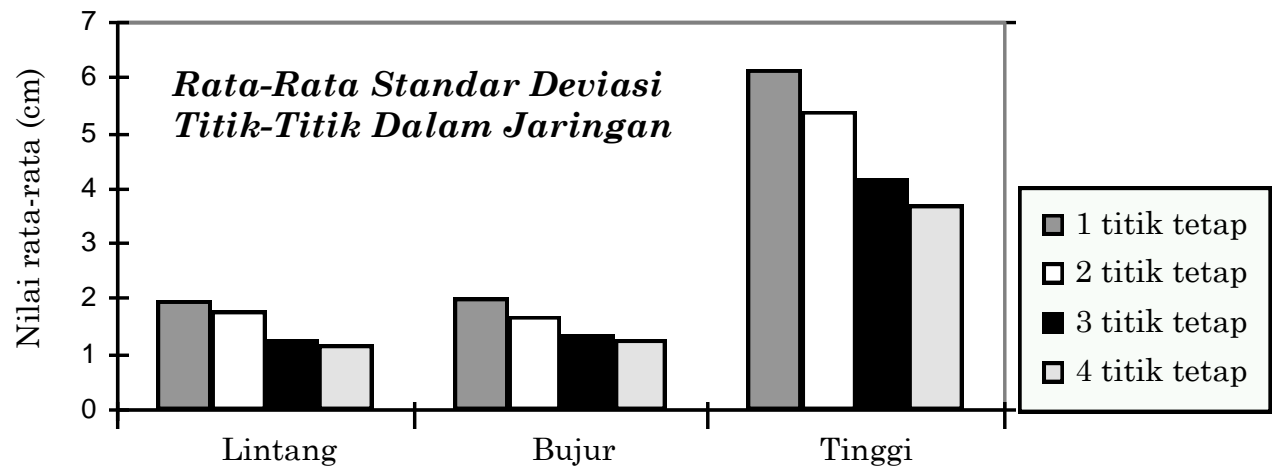

Gambar 8. Pengaruh jumlah titik tetap terhadap standar deviasi koordinat titik.

Penambahan titik tetap juga akan mempengaruhi nilai koordinat titik yang diperoleh, seperti yang ditunjukkan pada Gambar 9 berikut.

Dari Gambar 9 ini terlihat bahwa perubahan koordinat yang paling besar terjadi pada saat penambahan titik tetap dari satu menjadi dua. Sedangkan penambahan titik-titik tetap selanjutnya menyebabkan perubahan koordinat yang semakin mengecil.

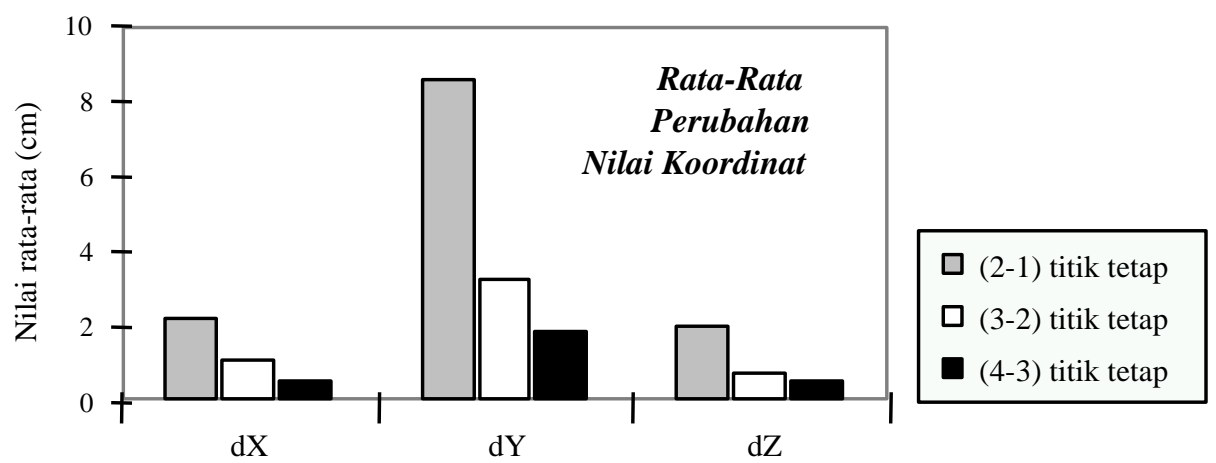

Gambar 9. Pengaruh jumlah titik tetap terhadap koordinat titik. 


\subsection{Pengaruh Distribusi Titik Tetap}

Distribusi titik tetap dalam jaringan akan mempengaruhi homogenitas kualitas koordinat titik dalam jaringan. Hal ini dapat ditunjukkan dengan hasil perhitungan yang diberikan pada Gambar 10 berikut.
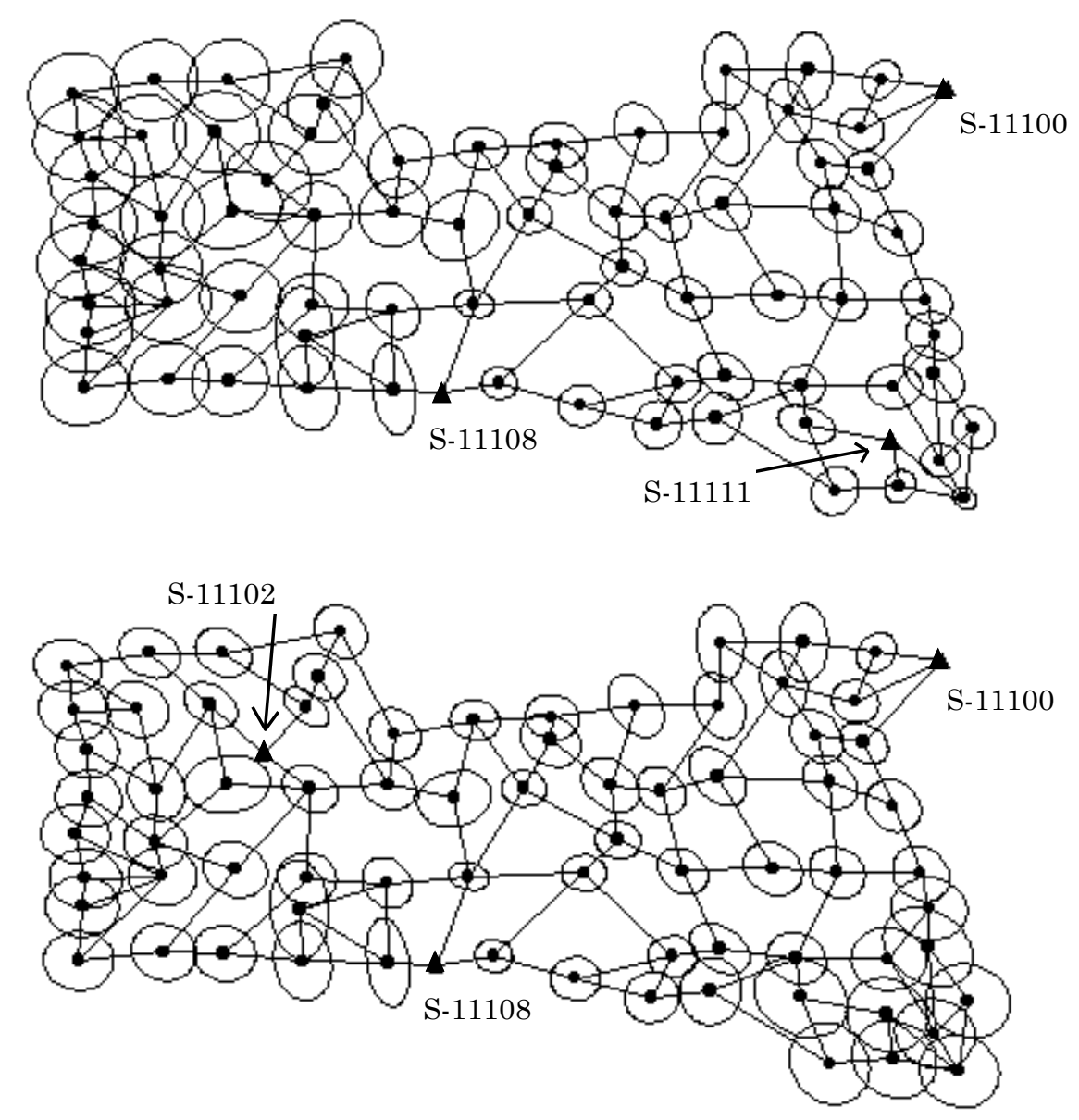

Gambar 10. Pengaruh distribusi titik tetap terhadap ketelitian titik-titik dalam jaringan (direpresentasikan dengan elips kesalahan titik).

Dari Gambar di atas terlihat bahwa kualitas dari koordinat titik-titik dalam jaringan akan tergantung pada posisi relatif dari titik-titik tersebut terhadap posisi dari titik-titik tetap. Secara umum kualitas dari koordinat titik-titik yang berada di antara titik-titik tetap akan relatif lebih baik dibandingkan dengan titik-titik yang berada di luar cakupan titik-titik tetap. Dengan kata lain kualitas jaringan akan relatif menjadi kurang baik ke arah bagian jaringan yang tidak mempunyai titik tetap. Hal ini dapat dilihat pada contoh pada Gambar 10, yaitu kualitas jaringan relatif kurang baik di bagian Barat dari jaringan sebelah atas dan di bagian Tenggara dari jaringan sebelah bawah.

Dari fakta di atas dapat disimpulkan bahwa untuk mendapatkan kualitas dari koordinat titik-titik dalam jaringan yang baik dan homogen, maka titik-titik tetap harus terdistribusi secara merata dalam jaringan. Jumlah optimal dari titik tetap yang diperlukan akan tergantung pada besarnya jaringan serta tingkat kualitas koordinat titik yang ingin dicapai.

\subsection{Pengaruh Jumlah Baseline Dalam Loop}

Untuk mempelajari efek dari jumlah baseline dalam suatu loop, digunakan tiga konfigurasi jaringan GPS seperti ditunjukkan pada Gambar 12 berikut. Jaringan ini merupakan bagian dari jaringan GPS Orde-3 Wates. 

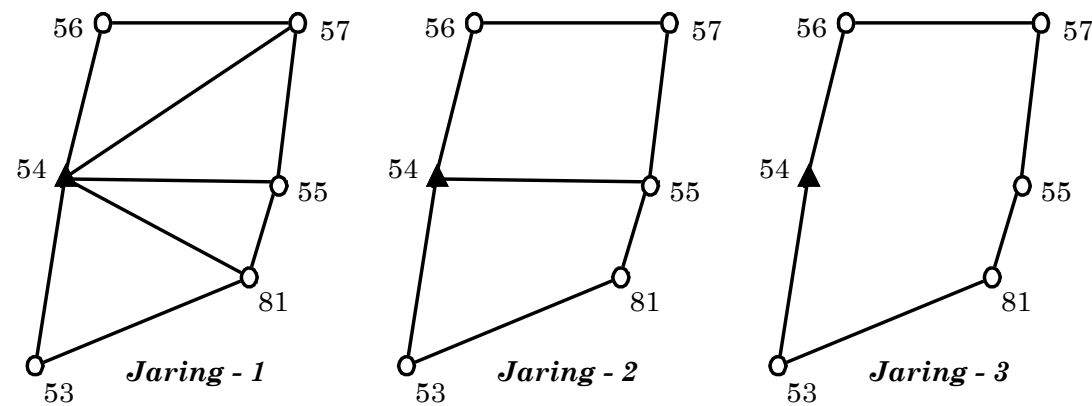

Gambar 12. Tiga konfigurasi jaringan yang digunakan untuk mempelajari pengaruh jumlah baseline dalam suatu loop.

Secara teoritis, seperti yang diindikasikan oleh faktor kekuatan jaringan pada Tabel-1, Jaring-1 akan memberikan kualitas hasil yang relatif paling baik dan Jaring-3 yang relatif paling buruk. Dengan kata lain semakin sedikit jumlah baseline dalam suatu loop, atau semakin banyak jumlah baseline dalam suatu jaringan, maka kualitas koordinat titik-titik yang diperoleh akan semakin baik. Dari Gambar 13 terlihat bahwa hipotesis tersebut secara empiris juga benar. Dari Gambar ini terlihat bahwa secara umum peningkatan jumlah baseline dalam loop akan memperburuk kepresisian dari koordinat titik-titik dalam jaringan. Ini ditunjukkan dengan membesarnya nilai standar deviasi serta sumbu panjang dari elips kesalahan absolut dan relatif.

Seperti halnya pada kasus penambahan titik tetap, penambahan jumlah baseline dalam suatu loop (pengurangan jumlah loop dalam jaringan) juga akan mempengaruhi nilai koordinat titik-titik dalam jaringan yang diperoleh. Secara teoritis perubahan nilai koordinat yang disebabkan oleh pengurangan jumlah loop dalam jaringan akan relatif lebih kecil dibandingkan dengan perubahan nilai koordinat yang disebabkan oleh penambahan titik tetap. Contoh dari kasus perubahan koordinat tersebut dalam wujud pergeseran posisi titik ditunjukkan pada Gambar 14 berikut.

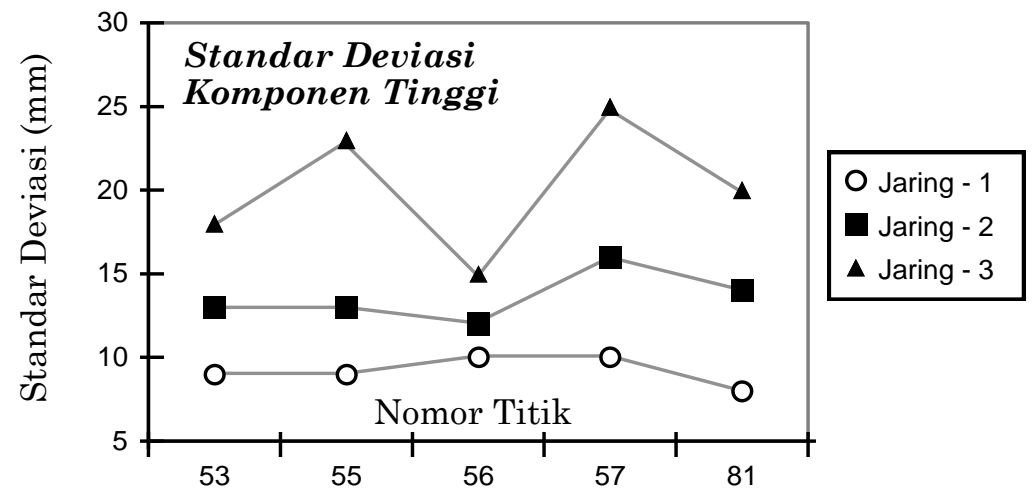

Sumbu Panjang Elips Kesalahan Absolut (mm)

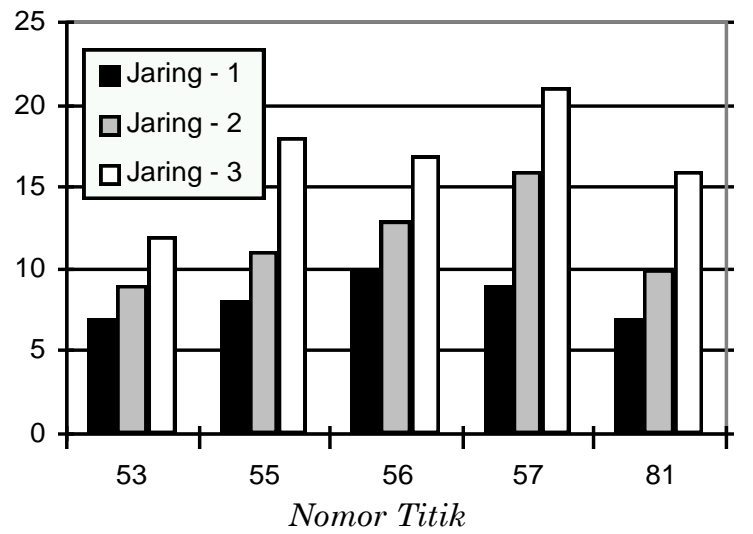

Sumbu Panjang Elips Kesalahan Relatif (mm)

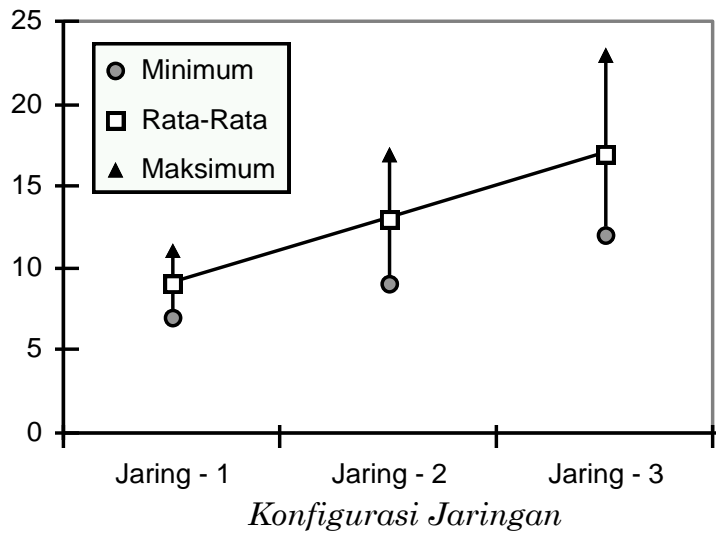

Gambar 13. Pengaruh jumlah baseline dalam loop terhadap kualitas dari koordinat titik. 
Dari Gambar 14 ini terlihat bahwa pergeseran posisi berbeda besarnya untuk masingmasing titik, tergantung tidak hanya pada lokasi titik dalam jaringan tapi juga konektivitasnya. Perlu ditekankan disini bahwa nilai pergeseran posisi titik akan sangat tergantung pada besar dan ukuran jaringan serta konfigurasi baseline dalam jaringan.

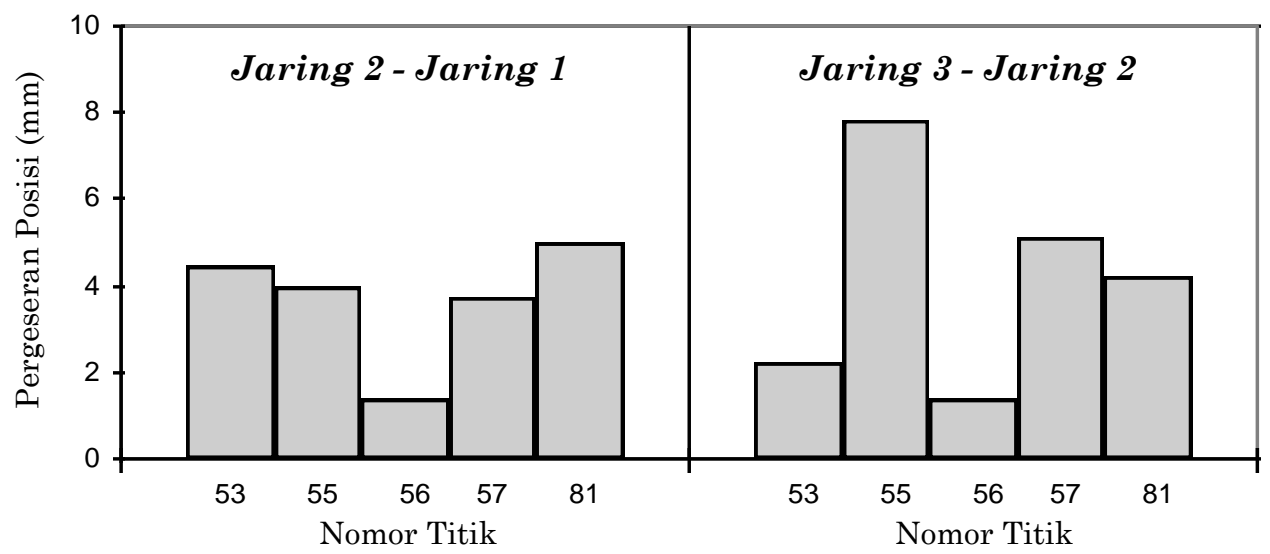

Gambar 14. Pergeseran posisi akibat penambahan jumlah baseline dalam loop.

\subsection{Pengaruh Konektivitas Titik}

Konektivitas titik, yaitu jumlah baseline yang terikat ke suatu titik, secara khusus akan mempengaruhi ketelitian dari koordinat titik tersebut, dan secara umum akan mempengaruhi kualitas jaringannya. Secara teoritis, seperti yang telah diilustrasikan dengan hasil pada Tabel 1, semakin tinggi konektivitas titiknya, yaitu semakin banyak jumlah baseline yang terikat ke suatu titik, maka kualitas dari koordinat titik tersebut akan semakin baik, dan sebaliknya. Akan tetapi pengaruh konektivitas titik terhadap jaringan sulit untuk dipelajari secara tersendiri karena efeknya bercampur dengan pengaruh dari jumlah loop dalam jaringan seperti yang telah dijelaskan di atas. Oleh sebab itu pengaruh konektivitas titik berikut ini akan dipelajari secara umum dengan melihat kecenderungan hasil yang diperoleh. Untuk itu digunakan empat konfigurasi jaringan GPS seperti ditunjukkan pada Gambar 15 berikut, dimana jaringan tersebut merupakan bagian dari jaringan GPS Orde-3 Wates.

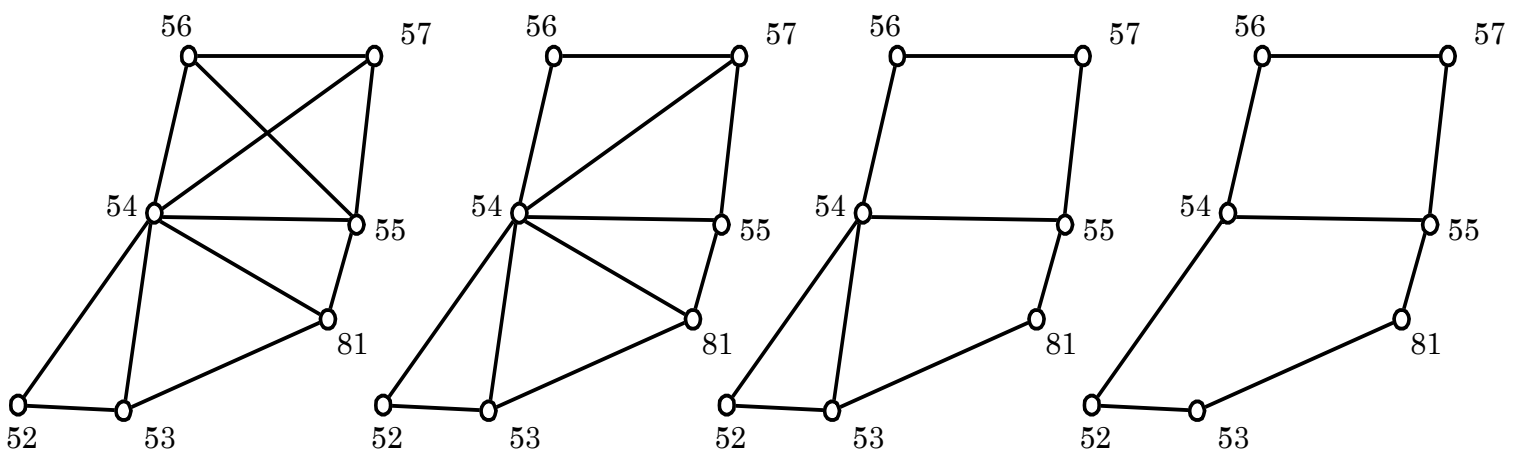

Gambar 15. Empat konfigurasi jaringan yang digunakan untuk mempelajari pengaruh konektivitas titik.

Keempat jaringan pada Gambar 15 tersebut diolah sendiri-sendiri, dan selanjutnya standar deviasi dari koordinat titik-titik yang diperoleh untuk seluruh jaringan tersebut dikelompokkan sesuai dengan konektivitas titiknya, seperti yang diberikan pada Tabel 2 berikut. 
Tabel 2. Pengaruh konektivitas titik terhadap kualitas koordinat titik-titik dalam jaringan.

\begin{tabular}{|c|c|c|c|c|c|c|c|}
\cline { 2 - 7 } \multicolumn{1}{c|}{} & \multicolumn{3}{c|}{ Nilai Kisaran } & \multicolumn{3}{c|}{$\begin{array}{c}\text { Nilai Rata-Rata } \\
\text { Konektivitas } \\
\text { Titik }\end{array}$} & \multicolumn{2}{c|}{\begin{tabular}{c} 
Standar Deviasi $(\mathrm{mm})$ \\
\cline { 2 - 7 }
\end{tabular}} & Lintang & Bujur & Tinggi & Lintang & Bujur & Tinggi & $\begin{array}{c}\text { Nilai Kisaran } \\
\text { Sumbu Panjang Elips } \\
\text { Kesalahan Absolut (mm) }\end{array}$ \\
\hline 2 & $5-6$ & $5-7$ & $10-20$ & 6 & 6 & 18 & $9-17$ \\
\hline 3 & $\approx 3$ & $3-5$ & $5-10$ & 3 & 3 & 8 & $8-10$ \\
\hline 4 & $\approx 3$ & $\approx 3$ & $\approx 5$ & 3 & 3 & 8 & $\approx 8$ \\
\hline
\end{tabular}

Dari Tabel di atas terlihat bahwa secara umum memang kualitas koordinat titik-titik dalam jaringan akan membaik seiring dengan meningkatnya konektivitas titiknya. Namun disini terlihat bahwa peningkatan kualitas yang relatif signifikan terjadi pada saat konektivitas titik ditingkatkan dari dua ke tiga, dan tidak pada saat ditingkatkan dari tiga ke empat. Oleh sebab itu untuk suatu jaringan titik-titik GPS, konektivitas titik sejumlah tiga baseline nampaknya sudah cukup memadai untuk digunakan. Disamping itu dari segi biaya survey, konektivitas titik sejumlah tiga baseline juga relatif akan lebih menguntungkan dibandingkan empat baseline atau lebih.

\section{PENUTUP}

Dari hasil-hasil perhitungan serta analisa-analisa yang telah diberikan di atas, ada beberapa hal yang dapat disimpulkan ataupun perlu diberi catatan berkenaan dengan pengaruh geometri jaringan terhadap ketelitian survey GPS, yaitu :

1. Pada suatu survey GPS, secara umum parameter-parameter geometri jaringan seperti jumlah dan distribusi dari titik tetap, jumlah loop dalam jaringan serta konektivitas titik-titiknya, akan mempengaruhi tidak hanya nilai koordinat dari titiktitik dalam jaringan tapi juga tingkat ketelitiannya.

2. Pada suatu survey GPS, jumlah titik tetap, jumlah loop dalam jaringan serta konektivitas titik yang sebaiknya digunakan akan tergantung pada ketelitian koordinat titik yang ingin dicapai serta ukuran dari jaringan GPS tersebut.

3. Untuk survey GPS yang menuntut ketelitian koordinat titik-titik pada tingkat $\mathrm{cm}$ sampai dm, panjang baseline dalam jaringan umumnya lebih kecil dari 10 sampai 15 $\mathrm{km}$, dan pengolahan datanya menggunakan perangkat lunak komersial, maka untuk memperoleh kualitas jaringan yang relatif baik dan homogen :

- jumlah titik tetap yang digunakan sebaiknya tidak kurang dari tiga,

- lokasinya terdistribusi secara merata dalam jaringan,

- jumlah baseline dalam suatu loop sebaiknya tidak lebih dari enam, dan

- konektivitas titik-titik dalam jaringan sebaiknya tidak kurang dari tiga baseline.

Akhirnya perlu ditekankan di sini bahwa kesimpulan-kesimpulan di atas perlu diverifikasi lebih lanjut dengan hasil-hasil pengolahan data dari jaringan-jaringan GPS lainnya.

\section{DAFTAR PUSTAKA}

Abidin, H.Z. (1995). Penentuan Posisi dengan GPS dan Aplikasinya. P.T. Pradnya Paramita, Jakarta. Cetakan pertama, ISBN 979-408-377-1, 109 hal.

Abidin, H.Z., A. Jones, J. Kahar (1995). Survey dengan GPS. P.T. Pradnya Paramita, Jakarta. ISBN 979-408-380-1. 153 hal.

Leick, A. (1995). GPS Satellite Surveying, Second Edition, John Wiley \& Sons, Inc., New York. 